\title{
RESULTS OF HUNTING THE RINGED PHEASANTS IN HUNTING GROUNDS OF AP VOJVODINA (SERBIA) IN 2014 and 2015
}

Zoran Ristić ${ }^{1^{*}}$, Milosava Matejević, Igor Ponjiger, Vasilije Tešić, Dajana Lulić

${ }^{1}$ Faculty of Science, University of Novi Sad

\section{Abstract}

The paper presents the results of two-year harvest of ringed pheasants in hunting grounds of Autonomous Province of Vojvodina. The results obtained in the first year of research indicate that 19.67\% (236) from total number of ringed and previously released pheasants (1200) were caught. The results for the entire observed period revealed that 1,499 pheasants were bagged, 399 of which were ringed. These results show that the share of ringed pheasants in the total number of harvested pheasants was $26.62 \%$, while the share of harvested ringed pheasants of the total number of entered ringed pheasant was $15.72 \%$, meaning that one of six released pheasants were bagged. Data related to pheasant chicks that were released in the hunting ground immediately before each hunt showed that the percentage of harvested ringed pheasants during the hunting season was $76.44 \%$, which indicates high percentage of harvesting ringed pheasant (observed for twoyear period).

Keywords: pheasant, artificial breeding, catch percent

${ }^{1^{*}}$ corresponding author: balzakova@yahoo.com 


\title{
REZULTATI ODSTRELA PRSTENOVANIH FAZANA U LOVIŠTIMA AP VOJVODINE (SRBIJA) 2014 i 2015. GODINE
}

\author{
Zoran Ristić, Milosava Matejević, Igor Ponjiger, Vasilije Tešić, Dajana Lulić \\ ${ }^{1}$ Prirodnomatematički fakultet, Univerzitet u Novom Sau
}

\section{Kratak sadržaj}

U radu su prikazani rezultati dvogodišnjeg istraživanja odstrela prstenovanih fazana u lovištima AP Vojvodine. Rezultati u prvoj godini ukazuju da je izlovljeno 19,66\% (236) u odnosu na ukupan broj prstenovanih i prethodno puštenih fazana (1.200). Rezultati za celokupan posmatrani period pokazuju da je ukupno odstreljeno 1.499 fazana od kojih je prstenovano bilo 399, što znači da je udeo prstenovanih u ukupnom broju izlovljenih fazana iznosio $26,62 \%$, a da je udeo izlovljenih prstenovanih fazana od ukupnog broja unetih prstenovanih fazana u lovišta iznosio $15,72 \%$. U ovakvom načinu pristupa tehnologije puštanja fazana u lovišta odstreljeno svako šesto fazansko pile koje je ispušteno. Podaci koji se odnose na fazančiće koji su puštani u lovište neposredno pre svakog lova pokazali su da je procenat izlova prstenovanih fazana u toku lovne sezone je iznosio je za dve posmatrane lovne godine (2014. i 2015) u iznosu od 76,44\%, što ukazuje na visok procenat izlova prstenovanih fazana.

Ključne reči: fazan, veštačka proizvodnja, procenat odstrela

\section{INTRODUCTION}

Pheasant is one of the main game species in most of Europe and that has led to the need for artificial breeding of this game. During the 1960's, the number of partridges in Central, Eastern and South Europe began to decrease, which led to mass production of pheasants and to its organized release into hunting grounds. This practice has continued until present days in most of European countries, although in Serbia the number of released pheasant has decreased in the last 15 years.

There are relatively small number of studies addressing weather conditions or causes of losses of released pheasants from artificial production or losses due to intensive agricultural production using modern equipment and pesticides (Burger 1966, Hessler et al., 1970). However, the pheasant is an important factor in maintaining diversity in agricultural systems and one of few game species which protection may be of financial importance. 
The aim of this research is to establish the percentage of usage of seasonal pheasant populations (the populations where a significant number of pheasant chicks was released) and to establish influence of seasonal factors and ways of hunting on sustainability of this game species.

\section{MATERIAL AND METHOD}

This research was conducted during 2013/14 and 2014/15 in several hunting grounds in Vojvodina (2013/14 - Kovačica, Ada, Maradik, Rusko Selo, Sonta and 2014/15 - Vrsac, Sid, Zitiste, Vrsac, Čerević and Sremska Mitrovica). Hunting grounds were characterized by different habitat conditions and pheasant chicks were of different age. At the age of 7-8 weeks, pheasants were ringed using plastic rings in different colors (depending on a hunters association) and transferred into shelters in hunting grounds. At the age of 12-13 weeks, they were released into an open part of the hunting ground. First hunt was two months later (mid-October) and it was followed with 9-12 hunting days in each hunting ground. After every hunt, all pheasant bags were counted, males and females separately, as well as the number of ringed pheasant. The obtained data were processed and presented in tables.

\section{RESULTS AND DISCUSSION}

During the hunting season, all ringed pheasants were recorded and results of the research (percentage of bagged pheasants that were released into hunting grounds two months before the start of the hunting season) are shown in Tables 1,2,3,4 and 5 .

Ring color was characteristic for every hunting ground in order to avoid errors in the calculation of harvest from individual hunting grounds. The number of hunting days per hunting ground ranged from 9-12, while number of hunters and hunting method differed significantly between hunting grounds. Total number of hunting days during the 2013/14 season was 54 , while total number of hunting participants was 724 . Total number of hunting days during the 2014/15 season was 90 with the total number of hunters being 800 . 
Table 1. Results of hunting of pheasants that were released into hunting grounds two months before the hunting season 2013/14

\begin{tabular}{|c|c|c|c|c|c|c|c|}
\hline $\begin{array}{c}\text { Hunting } \\
\text { grounds }\end{array}$ & $\begin{array}{c}\text { Hunting } \\
\text { days }\end{array}$ & Hunters & $\begin{array}{c}\text { Released } \\
\text { ringed } \\
\text { pheasants }\end{array}$ & $\begin{array}{c}\text { Bagged, } \\
\text { total }\end{array}$ & $\begin{array}{c}\text { Bagged, } \\
\text { ringed } \\
\text { ged bag- } \\
\text { \%ed rin- } \\
\text { ged from } \\
\text { total catch } \\
\text { ged, from } \\
\text { total } \\
\text { ringed } \\
\text { released }\end{array}$ \\
\hline Kovačica & 12 & 63 & 200 & 28 & 19 & 67.86 & 9.50 \\
\hline Ada & 9 & 80 & 200 & 77 & 37 & 48.05 & 18.50 \\
\hline Maradik & 12 & 180 & 200 & 119 & 54 & 45.38 & 27.00 \\
\hline Rusko & 11 & 401 & 600 & 209 & 126 & 60.29 & 21.00 \\
\hline Selo & 54 & 724 & 1200 & 433 & 236 & 54.50 & 19.67 \\
\hline Total & 54 & & & & & & \\
\hline
\end{tabular}

Table 2. Results of hunting pheasants that were released into hunting grounds two months before the hunting season 2013/14, according to sex

\begin{tabular}{|c|c|c|c|c|c|c|}
\hline \multirow{2}{*}{$\begin{array}{c}\text { Hunting } \\
\text { grounds }\end{array}$} & \multicolumn{3}{|c|}{ Bagged, total } & \multicolumn{3}{c|}{ Bagged, ringed } \\
\cline { 2 - 7 } & Total & Male & Female & Total & Male & Female \\
\hline Kovačica & 28 & 19 & 9 & 19 & 14 & 5 \\
\hline Ada & 77 & 54 & 23 & 37 & 28 & 9 \\
\hline Maradik & 119 & 89 & 30 & 54 & 41 & 13 \\
\hline Rusko Selo & 209 & 169 & 40 & 126 & 74 & 52 \\
\hline Total: & 433 & 331 & 102 & 236 & 157 & 79 \\
\hline
\end{tabular}


Table 3. Results of hunting ringed pheasants released into hunting grounds in Vojvodina in 2015

\begin{tabular}{|c|c|c|c|c|c|c|c|}
\hline $\begin{array}{l}\text { Hunting } \\
\text { grounds }\end{array}$ & $\begin{array}{c}\text { Hunting } \\
\text { days }\end{array}$ & Hunters & $\begin{array}{c}\text { Released } \\
\text { ringed } \\
\text { pheasants }\end{array}$ & $\begin{array}{l}\text { Bagged, } \\
\text { total }\end{array}$ & $\begin{array}{c}\text { Bagged, } \\
\text { ringed }\end{array}$ & $\begin{array}{l}\% \text { of rin- } \\
\text { ged from } \\
\text { total catch }\end{array}$ & $\begin{array}{c}\% \text { of } \\
\text { ringed } \\
\text { bagged, } \\
\text { from total } \\
\text { ringed } \\
\text { released }\end{array}$ \\
\hline $\begin{array}{l}\text { Bačka } \\
\text { Topola }\end{array}$ & 7 & 66 & 200 & 96 & 33 & 34.38 & 16.50 \\
\hline 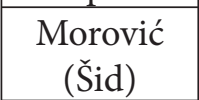 & 7 & 24 & 112 & 22 & 10 & 45.45 & 8.93 \\
\hline $\begin{array}{c}\begin{array}{c}\text { Višnjićevo } \\
(\text { Šid })\end{array} \\
\end{array}$ & 9 & 50 & 110 & 49 & 22 & 44.90 & 20.00 \\
\hline $\begin{array}{c}\text { Jamena } \\
(\text { Šid) }\end{array}$ & 10 & 65 & 120 & 34 & 17 & 50.00 & 14.17 \\
\hline Šid & 26 & 139 & 342 & 105 & 49 & 46.67 & 14.33 \\
\hline Čestereg & 9 & 102 & 100 & 42 & 11 & 26.19 & 11.00 \\
\hline Kupinovo & 6 & 79 & 196 & 38 & 17 & 44.74 & 8.67 \\
\hline Vršac & 5 & 42 & 100 & 38 & 4 & 10.53 & 4.00 \\
\hline $\begin{array}{l}\text { Sr. } \mathrm{Mi}- \\
\text { trovica }\end{array}$ & 37 & 372 & 400 & 750 & 49 & 6.53 & 12.25 \\
\hline Total A & 90 & 800 & 1,338 & 1,069 & 163 & 15.25 & 12.18 \\
\hline \multicolumn{8}{|l|}{ ADULTS } \\
\hline Čerević & 11 & 204 & 100 & 177 & 77 & 43.50 & 77.00 \\
\hline Čestereg & 10 & 108 & 149 & 99 & 99 & 100 & 66.44 \\
\hline $\begin{array}{c}\text { Petrova- } \\
\text { radin }\end{array}$ & 11 & 250 & 543 & 423 & 423 & 100 & 77.90 \\
\hline Total B & 32 & 562 & 792 & 699 & 599 & 85.69 & 75.63 \\
\hline Total $(A+B)$ & 122 & 1,362 & 2,130 & 1,768 & 762 & 43.10 & 35.77 \\
\hline
\end{tabular}


Table 4. Results of hunting ringed pheasants realesed into hunting grounds in Vojvodina in 2015

\begin{tabular}{|c|c|c|c|c|c|c|c|}
\hline $\begin{array}{l}\text { Hunting } \\
\text { grounds }\end{array}$ & $\begin{array}{c}\text { Hunting } \\
\text { days }\end{array}$ & Hunters & $\begin{array}{c}\text { Released } \\
\text { ringed } \\
\text { pheasants }\end{array}$ & $\begin{array}{c}\text { Bagged, } \\
\text { total }\end{array}$ & $\begin{array}{c}\text { Bagged, } \\
\text { ringed }\end{array}$ & $\begin{array}{l}\% \text { of rin- } \\
\text { ged from } \\
\text { total catch }\end{array}$ & $\begin{array}{c}\% \text { of } \\
\text { ringed } \\
\text { bagged, } \\
\text { from total } \\
\text { ringed } \\
\text { realesed }\end{array}$ \\
\hline $\begin{array}{l}\text { Bačka } \\
\text { Topola }\end{array}$ & 7 & 66 & 200 & 96 & 33 & 34.38 & 16.50 \\
\hline $\begin{array}{c}\text { Morović } \\
(\text { Šid })\end{array}$ & 7 & 24 & 112 & 22 & 10 & 45.45 & 8.93 \\
\hline $\begin{array}{c}\text { Višnjićevo } \\
\text { (Šid) }\end{array}$ & 9 & 50 & 110 & 49 & 22 & 44.90 & 20.00 \\
\hline $\begin{array}{c}\text { Jamena } \\
(\text { Šid })\end{array}$ & 10 & 65 & 120 & 34 & 17 & 50.00 & 14.17 \\
\hline Šid & 26 & 139 & 342 & 105 & 49 & 46.67 & 14.33 \\
\hline Čestereg & 9 & 102 & 100 & 42 & 11 & 26.19 & 11.00 \\
\hline Kupinovo & 6 & 79 & 196 & 38 & 17 & 44.74 & 8.67 \\
\hline Vršac & 5 & 42 & 100 & 38 & 4 & 10.53 & 4.00 \\
\hline $\begin{array}{c}\text { Sremska } \\
\text { Mitrovica }\end{array}$ & 37 & 372 & 400 & 750 & 49 & 6.53 & 12.25 \\
\hline Total & 90 & 800 & 1,338 & 1,069 & 163 & 15.25 & 12.18 \\
\hline
\end{tabular}

Table 5. Results of hunting ringed pheasants released into hunting grounds in Vojvodina in 2014 and 2015

\begin{tabular}{|c|c|c|c|c|c|c|c|}
\hline $\begin{array}{c}\text { Hunting } \\
\text { grounds }\end{array}$ & $\begin{array}{c}\text { Hunting } \\
\text { days }\end{array}$ & Hunters & $\begin{array}{c}\text { Released } \\
\text { ringed } \\
\text { pheasants }\end{array}$ & $\begin{array}{c}\text { Bagged, } \\
\text { total }\end{array}$ & $\begin{array}{c}\text { Bagged, } \\
\text { ringed } \\
\text { ringed } \\
\text { of rin- } \\
\text { ged from } \\
\text { total catch } \\
\text { bagged, } \\
\text { from total } \\
\text { ringed } \\
\text { released }\end{array}$ \\
\hline 2014 & 54 & 724 & 1,200 & 433 & 236 & 54.50 & 19.67 \\
\hline 2015 & 90 & 800 & 1,338 & 1,069 & 163 & 15.25 & 12.18 \\
\hline Total & 144 & 1,524 & 2,538 & 1,499 & 399 & 26.62 & 15.72 \\
\hline
\end{tabular}


The total bag for 2013/14 and 2014/15 was 1,499 pheasants. From that number, 399 pheasants were ringed, which means that the share of ringed pheasants in total number of bagged pheasants was $26.62 \%$. The share of bagged ringed pheasants in the total number of released ringed pheasant was $15.72 \%$. The real indicator of catch is $15.72 \%$ pointing to conclusion that in such approach and technology for releasing pheasants into hunting grounds, one of six released chicks was bagged.

The research of Pekić (Pekić, 1960) pointed on high percentage of pheasant losses in terms of the natural environment - 72\% (during the hunting season $9 \%$ was bagged and for whole year $28 \%$ survived). Hanuš (Hanuš, 1985) also preformed a research on percentage of released pheasants' bag. These results showed that percentage of released pheasant bag ranged from 22.2\% (minimum) to $55.6 \%$ (maximum). Catch of two-years-old pheasants was only $2.7 \%$ and the percentage of the catch of three-years-old pheasants was completely negligible.

According to the research performed in Ireland (Robertson, 1986; 1988) in controlled conditions with released 5-weeks-old pheasants, it was found that $69 \%$ of these pheasant died or disappeared until age of 12 weeks (the causes included: $45 \%$ foxes, $13 \%$ pesticide, $12 \%$ traffic and $4 \%$ other causes, while for $26 \%$ of losses the cause was unknown). The current research in hunting grounds in Vojvodina showed that the percentage of pheasant bag compared to released pheasants was very variable. Main reasons were diverse conditions on hunting site and mistakes in sheltering pheasants. Some research (Ristic et al., 1995; Zeremski et al., 1999) showed that the percentage of released pheasants' bag ranged from $7.40 \%$ to $39.30 \%$.

In this research, very small percentage of caught pheasants (9.50\%) was recorded in the hunting grounds of „Hunting Club Kovačica“. Main reason for this was the fact that hunting activities were organized near the settlement. Better percentage of caught pheasants $(60.29 \%)$ was observed in hunting ground of „Hunting Club Rusko Selo“, but the total number of hunters during the hunting season was far larger than in other clubs (401).

The research in the hunting ground Sonta, Čerević and Čestereg, where pheasants were released immediately before hunt, showed significantly higher percentage of ringed-pheasants bag (Table 6,7 and 8). 
Table 6. Results of hunting ringed pheasants released immediately before hunt (Sonta) in 2014

\begin{tabular}{|c|c|c|c|}
\hline & $\begin{array}{c}\text { Released } \\
\text { pheasants }\end{array}$ & Bagged & \% of bagged \\
\hline Non ringed & 185 & 125 & 67.57 \\
\hline Ringed & 170 & 131 & 77.06 \\
\hline Total & 355 & 256 & 72.11 \\
\hline
\end{tabular}

Table 7. Results of hunting ringed pheasants released into hunting grounds in Vojvodina in 2015

\begin{tabular}{|c|c|c|c|c|c|c|c|}
\hline $\begin{array}{c}\text { Hunting } \\
\text { grounds }\end{array}$ & $\begin{array}{c}\text { Hunting } \\
\text { days }\end{array}$ & Hunters & $\begin{array}{c}\text { Released } \\
\text { ringed } \\
\text { pheasants }\end{array}$ & $\begin{array}{c}\text { Bagged, } \\
\text { total }\end{array}$ & $\begin{array}{c}\text { Bagged, } \\
\text { ringed }\end{array}$ & $\begin{array}{c}\text { \% of rin- } \\
\text { ged from } \\
\text { ringed } \\
\text { total catch } \\
\text { from total } \\
\text { ringed } \\
\text { released }\end{array}$ \\
\hline Čerević & 11 & 204 & 100 & 177 & 77 & 43.50 & 77.00 \\
\hline Čestereg & 10 & 108 & 149 & 99 & 99 & 100 & 66.44 \\
\hline $\begin{array}{c}\text { Petrova- } \\
\text { radin }\end{array}$ & 11 & 250 & 543 & 423 & 423 & 100 & 77.90 \\
\hline Total & 32 & 562 & 792 & 699 & 599 & 85.69 & 75.63 \\
\hline
\end{tabular}

Table 8. Results of hunting ringed pheasants released into hunting grounds in Vojvodina in 2014 and 2015

\begin{tabular}{|c|c|c|c|c|c|c|c|}
\hline $\begin{array}{c}\text { Hunting } \\
\text { grounds }\end{array}$ & $\begin{array}{c}\text { Hunting } \\
\text { days }\end{array}$ & Hunters & $\begin{array}{c}\text { Released } \\
\text { ringed } \\
\text { pheasants }\end{array}$ & $\begin{array}{c}\text { Bagged, } \\
\text { total }\end{array}$ & $\begin{array}{c}\text { Bagged, } \\
\text { ringed } \\
\text { ringed } \\
\text { \%o of rin- } \\
\text { ged from } \\
\text { total catch } \\
\text { from total } \\
\text { ringed } \\
\text { released }\end{array}$ \\
\hline 2014 & 26 & 185 & 180 & 256 & 131 & 51.17 & 72.78 \\
\hline 2015 & 32 & 562 & 792 & 699 & 599 & 85.69 & 75.63 \\
\hline Total & 58 & 747 & 972 & 955 & 730 & 76.44 & 75.10 \\
\hline
\end{tabular}


Data from Tables 6, 7 and 8 are related to pheasants that were released in the hunting ground immediately before each hunt during the pheasant hunting season. There were 58 organized hunts and 792 ringed-pheasants were released. During the hunting season 2014 and 2015, the percentage of ringed-pheasants bag was $76.44 \%$, which indicates high percentage of harvesting ringed-pheasants.

Hanuš and Fischer (1983) pointed out the importance of respecting all principles in parenting techniques and releasing, since with the optimal environmental conditions and proper care of pheasants, the catch of 50\% of released males can be achieved. This is not the maximum score because there are hunting areas where the catch exceeds $60 \%$, but on average it is around $35 \%$ compared to the total number of released pheasant chickens.

According to the research of Ristic (2005), around 5.4 million pheasants were released in the hunting grounds in Vojvodina, mostly aged 5-6 and 7-8 weeks. For the period from 1973 to 2000, the percentage of catch ranged from the minimum recorded in 2000 (10.54\%) to a maximum of $28.77 \%$ in 1973.

\section{CONCLUSION}

Analyzed results indicate following conclusions:

- When it comes to the survival of artificially produced, released and harvested pheasants: they should be kept in shelters, which are made according to prescribed standards and provide good conditions for pheasant, since the average percentage of harvest in relation to the released pheasants two months before the hunt was $19.67 \%$ in 2014 and $12.18 \%$ in 2015 . Average percentage for both years was only $15.72 \%$;

- Pheasant hunt should be carried out from the beginning of the hunting season and hunting ground should rest for at least seven days after each hunt.

- For proper sheltering, hunting grounds with stable shelters are more appropriate: the results are better with pheasant chicks between 5 and 6 weeks of age, while in hunting grounds with temporary shelters it is better to use 7-8 weeks old chicks.

- In holdings where habitats lack perennial plants and the crops are harvested quickly, it is recommended to build enclosures for keeping pheasants until the hunting season and to release birds into hunting grounds immediately before hunt. In such way, the losses are minimized and catch percentage is higher - in our research it is $76.44 \%$, which is considered excellent result. 


\section{Acknowledgment}

This research was supported and funded by Ministry of Education, Science and Technological Development of Republic of Serbia, project No. TR -31084.

\section{References}

1. Burger, G. V.: Observations on aggressive behaviour of male ring-necked pheasants in Wisconsin. Journal of Wildlife Management 30, 1, 57-64, 1966.

2. Long, J. L.: Introduced birds of the world. David and Charles, London, UK, 1981

3. Hanuš V., Fišer Z.: "Bažant" - fazan (gajenje i lov), Nolit, Beograd, 1983.

4. Hanuš V., Fišer Z.: Vyposu šteni od shovanych bažantu do honiteb. In: Česky myslivecky svaz, str. 45, 1985.

5. Zeremski M., Novkov M., Beukovic M., Ristic Z.: Stepen preživljavanja fazančića puštenih u lovište iz naučnoistraživačkog rada LSS i LSV, Lovačke novine, 39, 12 (779), 9, 2000

6. Godišnji izveštaj o naučno istraživačkom radu LSZ, Beograd, oktobar, 2829, 1999.

7. Long, J. L.: Introduced birds of the world. David and Charles, London, UK., 1981.

8. Pekic B.: Koliko fazana ostane u životu, Lovačka revija, br. 5, 1960.

9. Robertson, P.A.: Ekologija i upravljanje veštački gajenih i divljih fazana (Phasanius colchicus) u Irskoj. Nacionalni univerzitet Irske, Dablin, 1986.

10. Robertson, P.A.: The survival of released pheasants (Phasianus colchicus) in Ireland. Journal of Zoology 214, 683-695, 1988.

11. Ristic Z., Đakovic D., Novkov M., Zeremski M.: Stepen preživljavanja fazančića unetih u lovište. Prvo saopštenje o rezultatima istraživanja u Vojvodini. U: Zbornik radova Lovačkog saveza Jugoslavije sa savetovanja u Novom Sadu, 93-98, 1995.

12. Ristic Z.: «Fazan», Novi Sad, 2005.

13. Ristic Z.: Procenat ulova ispuštenih odraslih fazana pred lov, Savremene tendencije u turizmu, hotelijerstvu i gastronomiji, Turizam, 10, 215 - 217, 2006.

Primljeno: 25.12.2015.

Odobreno: 15.01.2016. 